\title{
Review
}

\section{The Expanding Blaze: How the American Revolution Ignited the World, 1775-1848}

\author{
Jonathan Israel \\ Princeton University Press, Princeton, New Jersey, 2017, 768pp., \\ ISBN 9780691176604
}

Contemporary Political Theory (2019) 18, S274-S277. https://doi.org/10.1057/s41296018-0237-0; published online 27 June 2018

Jonathan Israel's book is an outstanding contribution to the intellectual history of the American Revolution and its global ramifications. With exceptional argumentative force and command of primary sources, Israel shows how radical philosophical notions of equality, democracy, free speech, toleration, and rejection of religious dogmatism went to war against aristocratic, often oligarchic, and always religious assailants. This ideological and intellectual battle is traced through its incubation in the American Revolution and its subsequent viral spread around the world. The breadth and depth of Israel's scholarship is awe-inspiring.

The Expanding Blaze exemplifies the promises and challenges of global intellectual historiography. The promise is that, by removing intellectual history from its national cloisters, we can better understand the full global scope of the intellectual movement at hand. One challenge of this approach is that national histories were rarely as constrained as it is often claimed, and what restrictions did pertain, merely served as useful banisters for clear and focused historical analyses. A subsequent challenge, then, is that international historiography requires broad linguistic and analytical proficiencies to master the diverse primary sources and complex interrelations, while simultaneously maintaining a coherent and compelling narrative structure. The Expanding Blaze overcomes these challenges in archetypal fashion.

Israel situates the American Revolution within two historical conflicts. First, the radical philosophical upheavals of the radical enlightenment, pitted against the moderate enlightenment and its conservative and theocratic allies. Second and nested within the first, is the battle between the radical democratic republicanism and the aristocratic/oligarchic federalist tradition. The book focuses on the latter.

Political theorists may find Israel's work of great value. I say 'may,' because theorists have obstinately overlooked Israel's other works of equal importance. On an array of topics - the enlightenment, the counter-enlightenment, revolution, freedom, equality, toleration, republicanism, radical democracy, aristocracy, oligarchy, and anti-oligarchic constitutionalism - political theorists have rarely

(C) 2018 Macmillan Publishers Ltd., part of Springer Nature. 1470-8914 Contemporary Political Theory Vol. 18, S4, S274-S277 www.palgrave.com/journals 
consulted or incorporated Israel's scholarship. It is hard to see this as anything but an act of academic self-harm. This review focuses on the elements of The Expanding Blaze that may be of interest to political theorists.

Loosely speaking, political theorists interested in republicanism are currently clustered around two perspectives: neo-republican critiques prioritizing statecentric institutions of non-domination, and more radical democratic and/or antioligarchic positions. The latter are often inspired by Machiavelli. Neither cluster will find unqualified support in The Expanding Blaze, and both will find certain core assumptions challenged. For example, neo-republicans - who tend to dismiss accusations of conservativism or anti-democratic/aristocratic assumptions by asserting that those concerns are either marginal or naïve - will find that these criticisms have deep roots in the American republican experience, and the radical enlightenment. This acknowledgment will make it much more difficult to ignore accusations of aristocratic agreement, given the vast historical evidence Israel musters. Israel is also eager to express the aristocratic commitments of certain philosophers who have often been taken as simply republican. John Locke's influence on the American Revolution - as well as the orthodox understanding of his role in the buildup to the Revolution - is a recurrent target in that regard. Israel argues that Locke's thought did not have a direct influence on the American Revolution, but rather played an important role in the ideological justification of the oligarchic reaction. Indeed, Locke's political theory, Israel contends, 'constituted an absolute obstacle to the forming of a democratic society' (p. 91).

In addition to pressing neo-republicans to acknowledge their aristocratic intellectual foundations, the book also pushes radical, democratic, and antioligarchic republican theorists to reflect on the marginal influence Machiavelli had on the American revolutionaries. On Israel's account, the Florentine Secretary's political philosophy played no significant intellectual role in the development of the most radical aspects of American republicanism (neither in name nor in terms of the content). Relatedly, theorists interested in the radical democratic aspects of Hannah Arendt's understanding of 'the political' as something distinct from philosophy may also be interested in Israel's rather strong argument regarding the importance of philosophy in shaping the American Revolution and the importance of that same philosophy in the French Revolution.

Israel's conceptual apparatus (radical v. moderate enlightenments) allows him to qualify the apparent hypocrisies in American republicanism - such as ascriptive hierarchies, racism, the colonial genocide, and the disastrous disavowals of the French and Haitian revolutions, among other things - as pertaining to different strands of republicanism. Israel is fast to associate those crimes with aristocratic republican thinkers:

Mainstream Enlightenment writers, ranging from Locke and Montesquieu to Hume and Robertson, offered widely diffused and adopted theories and

(C) 2018 Macmillan Publishers Ltd., part of Springer Nature. 1470-8914 Contemporary Political Theory Vol. 18, S4, S274-S277 S275 
doctrines useful for wresting land from Amerindians and classifying allegedly backward regions far from Europe as innately primitive besides defending black slavery. Such writers provided intellectual muscle for propping up exploitative colonial structures, but all were potentially undermined by the Radical Enlightenment's principle of 'universal and equal rights of mankind' (p. 363).

That critique exemplifies the overall tenor of the book. Israel surveys the myriad ways by which forces defending 'old-style European aristocracy, counter-enlightenment, ecclesiastical authority, monarchical forms, colonial oppression, and slavery' (p. 604) went to war against democracy, toleration, secularization, and universal human rights - and won. In contrast, Israel contends that only the radical enlightenment 'operated comprehensively and systematically against ancient regime social and legal structures en bloc, condemning not just slavery - even Burke was capable of that - but black social and political subordination to whites generally' (p. 364).

And yet, despite their 'comprehensive and systematic critiques,' the radicals also comprehensively and systematically failed following the American Revolution. What happened? Israel foists the lion's share of the blame on the reaction. Yes, the reaction was committed to their cause. But, it is presumably worth considering - if only because on this topic Israel is rather quiet - the political problems endogenous to the radical enlightenment and democratic republican traditions.

First, there is an eminent and thoroughgoing incapacity to institutionalize the ideals of the radical enlightenment. Part of the problem here may be ascribed to the kind of history Israel wants to write. Israel is concerned with both social history and intellectual history, but argues that whatever the developments in the social history that predated the American Revolution, the Revolution itself and its ultimate direction were defined by the intellectual history that clarified and crystalized those social forces. That historiographical approach crowds out considerations of institutional and constitutional politics. This methodological limitation is important, because it forecloses a line of critical inquiry into the failure of democratic republicans to think institutionally and, far more importantly, to create institutions that carry some of the burdens of those politics. 'The American Revolution,' Israel writes, 'may have begun a process to make the world anew, but by the late 1790s "the intruigers" appeared to be winning' (2017 p. 20). 'Intruigers' is Condorcet's term describing the religious and oligarchic interests that remained deeply entrenched in the institutional and ideological structures of post-Revolutionary America. From the outset, they committed themselves to undermining the democratic republican alternative, and they succeeded. Each victory of the radical enlightenment camp was rapidly swamped by a tide of oligarchic, religious, and popular reactionary responses, all bolstered by the institutions that supported those politics.

S276 (c) 2018 Macmillan Publishers Ltd., part of Springer Nature. 1470-8914 Contemporary Political Theory Vol. 18, S4, S274-S277 
Why did the more radical line fail so consistently? Israel seems to agree with Thomas Jefferson and John Adams, who, very late in the day, agreed that the American Revolution had failed because of 'insufficient Enlightenment.' Seen only through the prism of intellectual history, that may be an acceptable diagnosis, but it is certainly an insufficient account of the failure of radical republicanism. Reducing the failures of the radical wing to the 'insufficient enlightenment' of the masses avoids the more difficult questions. Institutions drive politics, and the radical enlightenment has proven inept at institution building. If the arc of republicanism bends towards oligarchy, it does so because oligarchs have monopolized the institutional logistics of republicanism. However, the institutional high ground was simply conceded.

The second associated problem is exemplified by Jefferson's assessment of the failure of the radical enlightenment: its inability to free itself from dependency on charismatic philosophers and leaders who will do the work of enlightenment. Politically, that kind of reliance is disastrous, because it is too personally demanding and too politically undependable. Tom Paine was a bellwether of this problem of demandingness. Following his initial explosive influence, he quickly became a figure of sustained aristocratic scorn, primarily for his atheism and democratic radicalism, and for having the mettle to criticize publicly the personality cult arising around George Washington. Jefferson's story is different, and speaks to the problem of dependability. When Jefferson took the helm, he espoused radical ideas while charging forward with policies of outstanding repression and regression (his opposition to the Alien and Sedition Acts was an exception). Israel tracks these failures/crimes with some precision - see especially chapters VII on 'Expropriating the Native Americans,' XIV on 'American and the Haitian Revolution,' and XV on 'Louisiana and the Principles of '76' - and they confirm the worst aspects of a politics reliant on leaders. And the justification for the expropriation of native lands? The natives suffered from, on Jefferson's account, insufficient enlightenment, of course (pp. 171-172).

These critical reflections stem from the successes, not the deficiencies, of Israel's scholarship. The Expanding Blaze - of which only a few fragments are surveyed here is a remarkable contribution to the history of the American Revolution and its global ramifications. Political theorists will find this book to be an essential whetstone for sharpening their historical understanding of democracy, republicanism, and oligarchy, and for honing normative theoretical claims. It is highly recommended.

J. Matthew Hoye Netherlands Institute for Advanced Study, 1012 CG Amsterdam, The Netherlands matthewhoye@gmail.com 